OPEN ACCESS

Edited by:

Kangyin Dong,

University of International Business and Economics, China

Reviewed by:

Haochang Yang,

Xi'an Jiaotong University, China

Guoxiang $\mathrm{Li}$,

Nanjing Normal University, China

Xuan Leng,

Southwestern University of Finance and Economics, China

${ }^{*}$ Correspondence:

Yu Gu

201901030001@stu.zuel.edu.cn

Specialty section:

This article was submitted to Sustainable Energy Systems and

Policies,

a section of the journal Frontiers in Energy Research

Received: 24 November 2021 Accepted: 13 December 2021

Published: 10 January 2022

Citation:

Feng C, Zhu X, Gu Y and Liu Y (2022) Does the Carbon Emissions Trading Policy Increase Corporate Tax Avoidance? Evidence from China. Front. Energy Res. 9:821219. doi: 10.3389/fenrg.2021.821219

\section{Does the Carbon Emissions Trading Policy Increase Corporate Tax Avoidance? Evidence from China}

\author{
Chen Feng ${ }^{1}$, Xingshu $\mathrm{Zhu}^{1}, \mathrm{Yu} \mathrm{Gu}^{2 *}$ and Yuecheng $\mathrm{Liu}^{2}$ \\ ${ }^{1}$ School of Public Economics and Administration, Shanghai University of Finance and Economics, Shanghai, China, ${ }^{2}$ School of \\ Public Finance and Taxation, Zhongnan University of Economics and Law, Wuhan, China
}

Based on the natural experiment of carbon emissions trading pilots in China, this paper investigates the effect of environmental regulation on corporate tax avoidance. The results show that: 1) Market-incentivized environmental regulation significantly increase the level of corporate tax avoidance. 2) Heterogeneity analysis shows that the effect is more obvious on the non-state-owned firms, firms with severe financing constraints, and firms in highly competitive industries. 3) We find that the reduction of cash flow is the channel for environmental regulation to affect corporate tax avoidance. 4) Further analysis shows that government subsidies can alleviate the enhancement of tax avoidance by environmental regulation. The more government subsidies a company receives, the less tax avoidance it has.

Keywords: carbon emissions trading policy, corporate tax avoidance, environmental regulation, cash flow, China

\section{INTRODUCTION}

Climate change is a global issue, which threatens human production and development, and has received widespread attention from governments. In 2016, The Paris Agreement proposed to achieve the goal of net-zero emissions in the second half of this century, setting off a global wave of "carbon neutrality". Subsequently, several countries put forward the goal of "carbon neutral". To control greenhouse gas emissions, governments have introduced a series of environmental regulations (Dong et al., 2018). Countries have favored carbon emissions trading policies for their ability to reduce carbon emissions in the most cost-effectively way. Since the European Union was the first to establish a carbon emissions trading market in 2005, several regional carbon trading systems have played an essential role in reducing $\mathrm{CO}_{2}$ emissions (Peng et al., 2015). The core idea of carbon trading is to impose total emission control on carbon emissions. Specifically, the government allocates carbon emission allowances to firms, which can only emit within the limits of the carbon emission allowances they own and purchase in the trading market. By internalizing the external emission cost into the production cost of firms, the establishment of a carbon emission trading system provides a compelling incentive for carbon emission reduction. Specifically, it reduces the total carbon emission and improves the carbon emission performance of firms (Zhang et al., 2019; Xuan et al., 2020; Zheng et al., 2021; Dong et al., 2022).

Theoretically, carbon emissions trading policy can achieve carbon emission reduction targets at the lowest total cost. However, in the short term, after the establishment of the carbon emissions trading market, carbon emissions will have the cost of compliance for firms in addition to the direct effect of reducing their carbon emissions. Implementing a carbon emissions trading policy is equivalent to imposing new constraints on corporate production and operation decisions. After establishing the carbon emissions market, firms need additional costs for quota trading, investment, 
innovation, management, and other behavior adjustments. Environmental regulation may also influence the adjustment of corporate tax decisions (Geng et al., 2021; Yu et al., 2021). As local governments pay more attention to environmental governance, the bargaining power of environmental firms increases, which may help firms obtain a more lenient tax collection environment and tax incentives (Mills et al., 2013). When firms have stronger connections with local governments, firms can reduce their own tax burden by exerting political influence (Yu et al., 2021). In addition, there may be a tradeoff between corporate tax behavior and corporate environmental performance disclosure as two important CSR elements. Fallana and Fallan (2019) found that firms with the highest mandatory environmental reporting disclosure also have less tax avoidance, while firms with higher voluntary disclosure have more tax avoidance. Sari and Tjen (2016) found that corporate environmental performance strengthens the negative relationship between corporate social responsibility and corporate tax avoidance. Higher corporate environmental performance scores are associated with less corporate tax avoidance. Strict environmental regulations may also cause changes in local taxing behavior by creating fiscal pressure for local governments, affecting corporate tax burden. Ye and Lin (2020) explored the effects of environmental regulations on local government taxing behavior and corporate tax burden in China and found that strict environmental regulations cause tax base erosion and lower local government tax revenues. Under fiscal pressure, local governments will increase tax rates by strengthening inspect, bringing additional tax costs to enterprises, leading to unfair tax distribution.

Environmental regulations can impose costs on firms. When facing liquidity constraints, firms may also adjust their tax avoidance behavior to increase retained earnings and cash flows through tax avoidance activities to undertake endogenous financing, alleviate financing constraints, and cope with external risks (Beck et al., 2014). Geng et al. (2021) found that environmental regulations promote corporate tax avoidance by increasing business risks and financing constraints. The environmental regulation has a spillover effect on corporate tax burden. In terms of costs, when faced with commandcontrolled environmental regulation, firms focus on end treatment to achieve immediate pollution reduction targets (Shao et al., 2021), while market-incentive environmental regulations can bring long-term compliance cost expectations for firms, and firms may have less incentive to avoid taxes. The "innovation offset effect" (Porter and Linde, 1995) induced by the implementation of carbon emissions trading may reduce or offset its burden on firms and increase their total factor productivity (Peng et al., 2021), improving their financial position and cash flow (Abrell et al., 2008; Oestreich and Tsiakas, 2015). Therefore, its impact on corporate tax avoidance is not clear. Next, based on the carbon emissions trading policy, this paper uses a quasinatural experiment approach to explore the causal effect of implementing market-incentivized environmental regulation on corporate tax avoidance.

This paper contributes to extant research in the following aspects. First, this paper broadens the understanding of how market-incentivized environmental regulation affect corporate behavior. Existing studies confirm the effects of environmental regulation on industrial structural upgrading (Wang et al., 2021), corporate total factor productivity (Gray, 1987), and corporate behaviors such as innovation, investment, location, export, and labor demand (Porter and Linde, 1995; Hering and Poncet, 2014; Cai et al., 2016; Shen et al., 2017; Shi et al., 2018; Li et al., 2021). Geng et al. (2021) and Yu et al. (2021) validate the effect of command and control on the behavior of firms based on the 11th Five-Year Plan and the Environmental Protection Law in China, respectively. Compared with other policies, market-incentivized environmental regulation can provide strong incentives for firms to sell emission permits that exceed the standards. After implementing the carbon pilot, firms can even sell emission permits that exceed the standard to gain additional revenue and compensate for the cost of environmental regulation (Porter and Linde, 1995). Does market-incentivized environmental regulation affect corporate tax avoidance? Based on a quasi-natural experiment approach, this paper reveals that firms may actively avoid taxes in response to the impact of carbon emissions trading, a market-incentivized environmental regulation policy. Second, the paper broadens the understanding of the external factors of corporate tax avoidance. Tax avoidance is a fundamental challenge commonly faced by developing countries, and even rich countries with strong monitoring systems face high rates of tax avoidance (Pomeranz and Vila-Belda, 2019). Existing research suggests that corporate tax avoidance is influenced by corporate characteristics such as size, the structure of ownership, characteristics of executives, internal control mechanisms, and other internal factors (Rego, 2003; Khurana and Moser, 2013; Richardson et al., 2013; Olsen and Stekelberg, 2016). In addition, there are external factors such as tax systems, collection techniques, product markets, media scrutiny, and economic policy uncertainty (Falkinger, 1995; Kleven et al., 2011; Kubick et al., 2015; Kanagaretnam et al., 2018; Dang et al., 2019). This paper explores the effect of carbon emissions trading policy, which are widely used by governments for carbon emission reduction, on corporate tax avoidance.

The rest of the paper is structured as follows. Section 2 introduces the background of China's carbon emissions trading policy and presents the research hypothesis. Section 3 presents the model construction and data description. Section 4 is the empirical findings, including baseline results and robustness checks. Section 5 focuses on heterogeneity and the mechanism of influence and analyzes the role of government subsidies, which is followed by conclusion in the last section.

\section{INSTITUTIONAL BACKGROUND AND RESEARCH HYPOTHESIS}

\subsection{China's ETS Emissions Policy}

As the world's largest carbon emitter, China set the goal of "striving to peak by 2030 and achieving carbon neutrality by 2060 " in 2020. According to the World Energy Statistics Yearbook 2020, China's carbon dioxide emissions reached 9.81 billion tons 
in 2019 , accounting for $28.6 \%$ of global emissions, far exceeding the United States, which is the second-largest emitter with 5.03 billion tons of carbon emissions, accounting for $14.6 \%$ of global emissions. At present, China's carbon emission intensity per unit of GDP is about three times the world average, which is still at a high level globally. In 2009, China proposed the goal to achieve a $40-45 \%$ reduction in carbon emissions per unit of GDP in 2020 compared to 2005. In response to global climate change and fulfilling its carbon emission reduction commitments, seven pilot carbon emission trading provinces and cities of Shenzhen, Shanghai, Beijing, Guangdong, Tianjin, Hubei, and Chongqing were identified in 2011. The carbon emission trading market was gradually launched in 2013 and2014 ${ }^{1}$. As of September 2017, the cumulative quota turnover of the seven pilot carbon markets exceeded 197 million tons of carbon dioxide equivalent, with a turnover of over RMB 4.5 billion. After implementing the pilot carbon emission trading market, China has achieved the carbon emission reduction targets of 17 and $18 \%$ per unit of GDP for the 12th and 13th Five-Year Plan periods in 2015 and 2020, respectively. Emission reduction targets were set in 2010 and 2015, respectively. The carbon emission intensity in 2020 will be reduced by $48.1 \%$ compared to 2005 , fulfilling the carbon emission reduction targets promised to the international community.

Unlike command-controlled environmental regulation, carbon emissions trading policy aim to treat the right to emit carbon emissions as an asset underlying and use market-based trading instruments to achieve $\mathrm{CO}_{2}$ emission reduction targets. The operation of China's carbon emissions trading policy is Chinese Emission Allowances (CEA), supplemented by Chinese Certified Emission Reduction (CCER). In the specific implementation, the relevant functional departments determine the maximum carbon emissions. Combining the number of regional emission units and the carbon emission intensity of each unit, the carbon emission allowances are decomposed into the compulsory emission companies. If the actual carbon emissions of the emissioncontrolled firms exceed the quotas, the firms can purchase their carbon dioxide emission rights for the excess emissions from the firms with surplus through the carbon trading platform. When the corporate carbon dioxide emissions are lower than the obtained quotas, they can sell the remaining carbon emission rights in the market. To complement this, a voluntary emission reduction market is introduced in addition to the quota market. Companies that exceed emissions standards are allowed to purchase certified emission reductions from companies that carry out "carbon offset" activities, and voluntary emission reduction companies can sell certified emission reductions to achieve profitability.

\subsection{Theoretical Analysis and Research Hypothesis}

Based on different logics, the effect of carbon emissions trading on corporate tax avoidance has different expectations. Therefore,

\footnotetext{
${ }^{1}$ In December 2016, a carbon emission trading market was also established in Fujian Province. The sample period of this paper is from 2008-2016, so Fujian Province is not taken into consideration
}

we propose two different hypotheses on the effect of carbon emissions trading policy on corporate tax avoidance.

Implementing carbon emissions trading policy may enhance the degree of corporate tax avoidance in the following ways. First, implementing carbon emissions trading pilot breaks the original equilibrium of enterprises and increases the cost of pollution control, allowance trading, or fines. Environmental regulations create additional expenses for firms, inevitably increasing their costs and affecting their competitive advantage (Zhao and Sun, 2015). When facing greater competitive pressure, firms avoid taxes to reserve more money to maintain their market position (Cai and Liu, 2009). Second, establishing the carbon trading market has prompted the public and government to pay more attention to climate change issues. Investors expect stricter regulations in the future, higher required rates of return will be demanded for high-emitting firms. The uncertainty of environmental regulatory policies further exacerbates the difficulty and cost of raising external finance for firms (Koch and Bassen, 2013; Jong et al., 2014). When the cost of exogenous financing is high and internal cash flow is insufficient, firms may use tax avoidance as a way to obtain funds (Beck et al., 2014; Edwards et al., 2016). Third, environmental regulation policy will cause increased uncertainty in the business environment, and the management of firms will become inaccurate in predicting future cash flows. Firms will tend to respond to future adverse risks by hoarding extra cash (Dudley and Zhang, 2016). Tax avoidance can reduce corporate cash outflows and the cost of raising external funds. The degree of corporate tax avoidance for precautionary motives may be enhanced. Fourth, carbon emission policies may enhance corporate social responsibility and reputation, reducing the opportunity cost of reputation loss when corporate tax avoidance is detected, so firms may improve the degree of tax avoidance. The corporate tax avoidance faces the cost of being discovered and penalized by tax authorities and the corresponding loss of reputation (Allingham and Sandmo, 1972). Godfrey (2005) argued that firms can rely on a good social reputation to improve their ability to resist risks, and firms may see the fulfillment of environmental responsibility and disclosure of environmental information as a way to enhance a good reputation. Firms are less negatively affected by tax avoidance risks and thus enhance their tax avoidance activities. Although firms can choose other ways to counteract the risk of carbon emissions trading policies, tax avoidance has less impact on normal production and business activities than cutting expenses and investments (Edwards et al., 2016). In addition, the risk of tax avoidance for firms is not too high due to the large information asymmetry (Cai and Liu, 2009). When corporate liquidity decreases and faces financing constraint dilemmas, the opportunity cost of corporate tax avoidance consequently decreases and, at the margin, induces more corporate tax avoidance. As a result, we propose hypothesis 1.

Market-incentivized environmental regulation represented by carbon emissions trading will enhance corporate tax avoidance.

Implementing carbon emissions trading policies may weaken the degree of tax avoidance of firms in the following ways. First, 
carbon emissions trading may bring additional benefits to firms. Liu et al. (2021) show that carbon emissions trading policies increase the non-operating income of firms included in carbon emission controls. Meanwhile, existing studies find that carbon emissions trading may increase corporate total factor productivity (Peng et al., 2021), and improve their financial position and cash flow (Abrell et al., 2008; Oestreich and Tsiakas, 2015). Since corporate tax avoidance is not costless, the incentive to avoid taxes will decrease when the financial performance of firms improves. Second, environmental regulations can cause firms to reduce, shut down, or relocate their production, resulting in a potential loss of revenue for local governments and creating fiscal pressure on governments. Unlike other countries that usually take initiatives to cut spending in response to fiscal pressure, local governments in China tend to increase revenue by strengthening tax collection efforts to raise corporate tax rates when facing fiscal pressure from reduced revenue (Chen, 2017; Ye and Lin, 2020). When the tax authorities strengthen inspect, the space for corporate tax avoidance is compressed, and the degree of corporate tax avoidance is reduced (Allingham and Sandmo, 1972). Third, the implementation of carbon emissions trading policy will enhance the environmental information disclosure of enterprises, which will reduce corporate tax avoidance. Although the carbon market disclosure in China is weak in terms of the carbon markets in each pilot region (Dong et al., 2019), implementing the carbon emissions trading policy still strengthens corporate carbon information disclosure to some extent. Environmental information disclosure increases corporate visibility and liquidity, attracting public scrutiny and government regulation. When firms are subject to stricter regulation, the probability of corporate tax avoidance being detected increases and may reduce tax avoidance activities. Wang et al. (2020) found that corporate environmental information disclosure can improve corporate take performance, and the improvement of corporate financial performance may also reduce corporate tax avoidance to some extent. As a result, we propose hypothesis 2 .

Market-incentivized environmental regulation represented by carbon emissions trading will decrease corporate tax avoidance.

\section{STUDY DESIGN}

\subsection{Model Settings}

Carbon emissions trading policies are implemented gradually at the provincial level with rich temporal and regional differences. This paper explores the effect of environmental regulation on corporate tax avoidance using a quasi-natural experiment with carbon emissions trading policy carried out in seven regions after 2011, using a difference-in-differences approach (DID). The specific model is as follows.

$$
D_{D B T D_{i t}}=\alpha+\beta E T S_{i t}+\gamma X_{i t}+\mu_{i}+\delta_{t}+\varepsilon_{i t}
$$

where $D D B T D_{i t}$ indicates corporate tax avoidance of firm $i$ in year $t$. ETS $S_{i t}$ represents whether firm $i$ is in the pilot area of carbon emission trading reform in year $t$. If firm $i$ is in the pilot area in year $t$, then $E T S_{i t}$ is 1 . Otherwise, it is $0 . X_{i t}$ is the set of control variables, $\mu_{i}$ and $\delta_{t}$ represent firm and year fixed effect, and $\varepsilon_{i t}$ is the error term.

\subsection{Variables and Data}

\subsubsection{The Explained Variable}

The explained variable is the extent of corporate tax avoidance. The difference between corporate pre-tax accounting earnings and taxable earnings effectively conveys corporate tax evasion (Wilson, 2009). In general, the greater the degree of corporate tax evasion, the greater the difference between pre-tax accounting earnings and taxable earnings. Desai and Dharmapala (2006) developed a method to measure corporate tax avoidance regarding the difference between pre-tax accounting earnings and taxable earnings after excluding corporate surplus management. The regression model is as follows.

$$
\begin{gathered}
B T D_{i t}=\alpha_{0}+\alpha_{1} \times T A_{i t}+\mu_{i}+\varepsilon_{i t} \\
\text { DDBTD }_{i t}=\mu_{i}+\varepsilon_{i t}
\end{gathered}
$$

In model (2), $B T D_{i t}$ indicates tax accounting difference of firm $i$ in year $t$, measured as the difference between the pre-tax accounting profit and the taxable income of the firm at the end of the year as a share of total assets. $T A_{i t}$ is the accrued profit of firm $i$ in year $t$, measured by the difference between net profit and net cash flow from economic activities as a percentage of total assets. The residual term $D D B T D_{i t}$ is the tax difference after excluding the surplus management factor, which is used to measure the tax avoidance of the firm by regressing the tax difference $B T D_{i t}$ on the total accrued profit $T A_{i t}$. The larger the value of $D D B T D_{i t}$ the larger the corporate tax difference and the higher the degree of corporate tax avoidance.

\subsubsection{Explanatory Variable}

The explanatory variable is the dummy variable of carbon emissions trading policy implementation $\left(E T S_{i t}\right)$, which represents whether firm $i$ is in a pilot region of carbon emissions trading policy in year $t . E T S_{i t}$ is the interaction term of the policy dummy variable (Treatment ${ }_{i}$ ) and the time dummy variable $\left(\right.$ Post $\left._{t}\right)$. Treatment $i=1$ represents the dummy variable of whether the pilot carbon emission trading policy is implemented in the region where the firm is located, including Beijing, Tianjin, Shanghai, Chongqing, Hubei, and Guangdong (Shenzhen belongs to Guangdong), and Treatment $_{i}=0$ represents the region where the firm does not implement the pilot carbon emission trading policy. Post $_{t}=1$ represents the dummy variable after implementing carbon emissions trading policy. Specifically, the starting time of carbon emissions trading varies among regions, with Shanghai, Beijing, Guangdong, and Shenzhen starting the pilot in 2012, Hubei, Tianjin, and Chongqing starting their pilot projects in 2013.

\subsubsection{Control Variables}

Based on previous studies, we also control for other characteristics that may affect tax avoidance, including Size, return on assets (ROA), asset-liability ratio (Leverage), the 
TABLE 1 | Descriptive statistics.

\begin{tabular}{lccccc}
\hline Variable & Observation & Mean & Std.Dev & Min & Max \\
\hline DDBTD & 9,008 & -0.012 & 0.034 & -0.172 & 0.155 \\
ETS & 9,008 & 0.263 & 0.440 & 0.000 & 1.000 \\
Size & 9,008 & 21.974 & 1.204 & 19.646 & 25.652 \\
ROA & 9,008 & 0.052 & 0.041 & 0.000 & 0.205 \\
Leverage & 9,008 & 0.409 & 0.196 & 0.046 & 0.856 \\
Capital & 9,008 & 0.244 & 0.154 & 0.004 & 0.698 \\
Inventory & 9,008 & 0.153 & 0.122 & 0.003 & 0.675 \\
Age & 9,008 & 2.640 & 0.398 & 0.693 & 3.611 \\
Cash & 9,008 & 0.190 & 0.131 & 0.014 & 0.698 \\
\hline
\end{tabular}

intensity of fixed assets (Capital), inventory density (Inventory), Age, and level of cash holdings (Cash). Of these, Size is calculated as the $\log$ of the corporate total assets, ROA is measured as net income to total assets, Leverage is calculated as total liabilities to total assets, Capital is calculated as fixed assets to total assets at year-end, Inventory is calculated as net inventory to total assets at the end of year, Age is calculated as the log of the corporate years of existence, and Cash is calculated as the balance of cash and cash equivalents as a share of total assets (Stickney and McGee, 1982; Zimmerman, 1983; Gupta and Newberry, 1997; Rego, 2003; Cai and Liu, 2009; Richardson et al., 2016; Yu et al., 2021).

\subsection{Data Sources}

The firm-level data used in this paper are obtained from the China Stock Market and Accounting Research (CSMAR) database. The sample period of this paper is from 2008-2016. We cleaned the data as follows. First, we only kept the industrial firm because the industries covered by the carbon emission trading market are mainly industrial firms. To ensure the accuracy of the estimation results, we removed the non-industrial firms. Second, we removed the samples with ST and $\mathrm{ST}^{*}$ in the current year. Third, we removed the samples with missing main variables. Fourth, we removed the samples with the actual tax burden greater than 1 or less than 0 . Fifth, we performed winsorize treatment on continuous variables at the 1 and $99 \%$ quartiles. In the section on robustness checks, this paper employs some macro-level variables, and the data are obtained from the China Statistical Yearbook. Table 1 presents the descriptive statistics for main variable.

\section{EMPIRICAL RESULTS}

\subsection{Basic Regression Results \\ 4.1.1DID Estimation}

Table 2 reports the baseline regression results of model 1). Column 1) of the regression controls only for annual fixed effects and firm fixed effects only. And in column 2), we further control firm-level factors. We find that coefficients are both positive, which are significant at the $5 \%$ confidence level. This result suggests that implementing the pilot of carbon emissions trading increases the tax avoidance, indicating that market-incentivized environmental regulation have an elevating effect on corporate tax avoidance. This result verifies hypothesis 1 . In terms of control variables, consistent with the findings of existing studies, the coefficient of the corporate profitability variable is significantly
TABLE 2 | Baseline results.

\begin{tabular}{|c|c|c|c|c|}
\hline \multirow[t]{3}{*}{ Dependent variable } & DDBTD & DDBTD & DDBTD & DDBTD \\
\hline & \multicolumn{2}{|c|}{ DID } & \multicolumn{2}{|c|}{ PSM-DID } \\
\hline & (1) & (2) & (3) & (4) \\
\hline ETS & $\begin{array}{c}0.0091^{\star \star \star} \\
(0.0035)\end{array}$ & $\begin{array}{l}0.0083^{\star \star} \\
(0.0034)\end{array}$ & $\begin{array}{c}0.0094^{\star \star \star} \\
(0.0035)\end{array}$ & $\begin{array}{l}0.0086^{\star \star} \\
(0.0035)\end{array}$ \\
\hline Size & & $\begin{array}{c}0.0008 \\
(0.0014)\end{array}$ & & $\begin{array}{c}0.0012 \\
(0.0015)\end{array}$ \\
\hline Roa & & $\begin{array}{c}0.1721^{\star \star \star} \\
(0.0274)\end{array}$ & & $\begin{array}{c}0.1745^{\star \star \star} \\
(0.0277)\end{array}$ \\
\hline Leverage & & $\begin{array}{c}-0.0244^{\star \star \star} \\
(0.0058)\end{array}$ & & $\begin{array}{c}-0.0249^{\star \star \star} \\
(0.0059)\end{array}$ \\
\hline Capital & & $\begin{array}{l}-0.0075 \\
(0.0062)\end{array}$ & & $\begin{array}{l}-0.0092 \\
(0.0064)\end{array}$ \\
\hline Inventory & & $\begin{array}{c}-0.0214^{\star} \\
(0.0110)\end{array}$ & & $\begin{array}{c}-0.0214^{*} \\
(0.0110)\end{array}$ \\
\hline Age & & $\begin{array}{c}0.0003 \\
(0.0052)\end{array}$ & & $\begin{array}{l}-0.0012 \\
(0.0052)\end{array}$ \\
\hline Cash & & $\begin{array}{c}-0.0134^{\star *} \\
(0.0055)\end{array}$ & & $\begin{array}{c}-0.0138^{\star \star} \\
(0.0055)\end{array}$ \\
\hline Constant & $\begin{array}{c}-0.0071^{\star \star \star} \\
(0.0021)\end{array}$ & $\begin{array}{l}-0.0178 \\
(0.0317)\end{array}$ & $\begin{array}{c}-0.0075^{\star \star \star} \\
(0.0022)\end{array}$ & $\begin{array}{l}-0.0209 \\
(0.0320)\end{array}$ \\
\hline Observations & 9,008 & 9,008 & 8,935 & 8,924 \\
\hline R-squared & 0.0066 & 0.0352 & 0.0064 & 0.0361 \\
\hline Firm FE & Y & Y & Y & Y \\
\hline Year FE & Y & Y & Y & Y \\
\hline
\end{tabular}

Note: ${ }^{* * *},{ }^{* *}$, and * represent the significance levels at 1, 5, and 10\%, respectively. The robust standard error is reported in parentheses.

positive, indicating that tax avoidance is relatively more frequent among enterprises with higher profitability. The coefficient of the corporate gearing variable is significantly negative, indicating that companies with high gearing have relatively fewer tax avoidance activities and lower tax avoidance. Inventory intensity is negatively correlated with tax avoidance behavior, and the higher the inventory intensity, the lower the degree of corporate tax avoidance. The higher the level of cash flow of the enterprise, the more liquid the enterprise is and the lower the degree of tax avoidance of the enterprise.

\subsubsection{PSM-DID Estimation}

Considering the effect of possible group differences between the treatment and control groups on the policy assessment results, this paper uses PSM-DID for robustness test. Drawing on Blundell and Costa Dias (2020), we use a year-by-year matching method to find a matching treatment group for each year. The specific matching process using PSM is as follows. In each sample year, the propensity score is calculated using Logit model with whether the sample firm is a firm in the carbon trading region as the dependent variable and Size, Age, Leverage, Capital, and ownership nature as the independent variables. Then, based on the calculated propensity score, we use one-toone neighbor matching to screen out companies similar to the treatment group ${ }^{2}$. After eliminating the unsuccessful matches, a

${ }^{2}$ In order to ensure the reliability of the matching results, we carry out a matching balance test. It is found that the observable variables of the treatment group and the control group are basically not significantly different after matching 


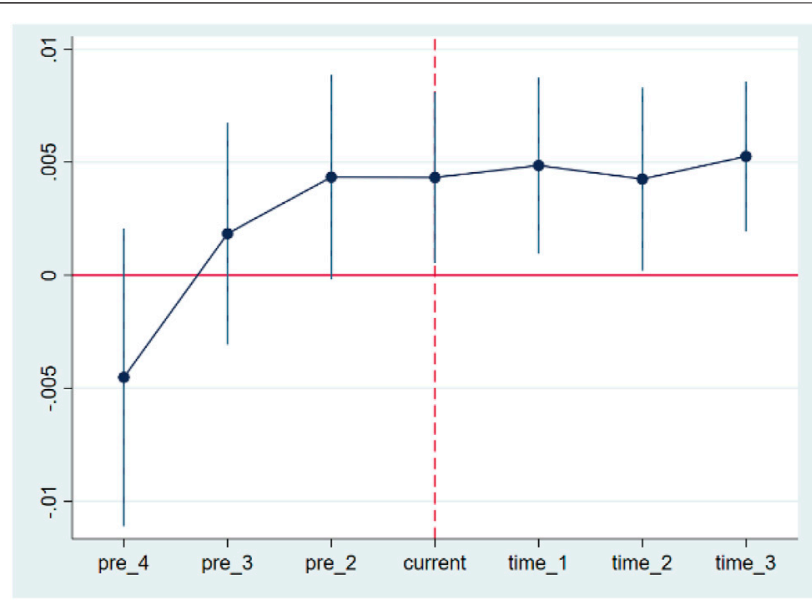

FIGURE 1 | Parallel trend test.

new treatment group with similar characteristics to the treatment group was obtained, and the DID estimation of the model 1) was re-estimated. The specific results are presented in columns 3) and 4) of Table 2. It can see that the implementation of the carbon emissions trading policy still has a significant elevating effect on the level of corporate tax avoidance. This indicates the results of DID estimation are robust.

\subsection{Parallel Trend Test}

One of the basic prerequisites for the validity of the DID approach is the assumption of parallel trends, i.e., if the treatment group is not subject to policy interventions, its trend effect should be the same as that of the control group, i.e., the difference between the treatment and control groups should not change over time. Since the "counterfactual" state in which the treatment group is not subject to policy shocks is unobservable, the only way to test for differences in time trends between the treatment and control groups is by looking at the pre-pilot period. To test whether the time trends between the treatment and control groups were the same before the reform, we refer to the time analysis proposed by Jacobson et al. (1993) to determine the dynamic effect of the carbon trading pilot. The model is set up as follows.

$$
D D B T D_{i t}=\alpha+\beta_{k} \sum_{k \geq-4}^{3} E_{T S} S_{t_{i 0+k}}+\gamma X_{i t}+\mu_{i}+\delta_{t}+\varepsilon_{i t}
$$

Among them, the dummy variable $E T S_{t_{i 0+k}}$ is a series of time dummy variables, $t_{i 0}$ denotes the year when the carbon trading emission rights policy started to be implemented, $k$ represents the $\mathrm{k}$-th year of carbon trading emission rights policy implementation $(\mathrm{k} \leq-4,-3,-2,0,1,2,3)$, and the omitted year is $\mathrm{k}=-1$, so the reported treatment effect is relative to the time of the year before the reform started. By focusing on the coefficient $\beta_{k}$, it is possible to determine whether there is a pre-existing exante trend between the control and treatment groups. Figure 1 shows the distribution of the coefficient $\beta_{k}$ for each year before and after the implementation of the carbon emissions trading policy. We see that the coefficient of $\beta_{k}$ is not statistically significant before implementing the carbon trading emission rights policy, which implies that there is no systematic difference between the treatment group and the treatment group before implementing the policy assumption of parallel trend holds. Meanwhile, after implementing the carbon trading pilot, the effect of environmental regulation on corporate tax avoidance is revealed.

\subsection{Contemporaneous Policy Interference}

In addition to implementing carbon emissions trading policy, China has adopted several other environmental regulatory policies during the sample period of this paper. Implementing other policies during the sample period may lead to biased estimates, and we test the robustness of our results by excluding these confounding effects.

\subsubsection{Excluding the Confounding Effect of the Emissions Trading Reimbursement and Trading Policy (ETRT)}

Since 2007, China has gradually implemented a system of paid use and trading of emission rights in 11 regions in Jiangsu, Zhejiang, Tianjin, Hubei, Hunan, Inner Mongolia, Shanxi, Chongqing, Shaanxi, Hebei, and Henan to reduce pollutant emissions. Within the sample interval, Chongqing, Hubei, and Tianjin are pilot regions of both carbon trading rights system and the emissions trading reimbursement and trading system, which may make our observed results not by carbon trading rights system but by emission rights paid use and trading system. Therefore, in column 1) of Table 2, we control for the dummy variable of whether the firm was a pilot of ETRT in the year. The conclusions show that the coefficients of the ETS variables remain significant at the $5 \%$ level, and we do not observe a decrease in the coefficients compared to the results in column 2) of Table 2, implying that the baseline results are not affected by the ETRT.

\subsubsection{Excluding the Interference of Low-Carbon Provinces and Low-Carbon Cities Pilot Policies}

To control greenhouse gas emissions, China launched pilot lowcarbon provinces and low-carbon cities in five provinces and eight cities in 2010, with the explicit goal of reducing carbon emission intensity in the pilot areas ${ }^{3}$. In 2012, the country further expanded the scope of the pilot program and launched the second batch of national pilot low-carbon provinces and low-carbon cities. Implementing of the pilot policies of low-carbon provinces, regions, and cities likewise increases the degree of environmental regulation in the pilot areas, affecting the accuracy of the baseline regression estimates. Column 2) of Table 3 reports the estimation results after controlling for the dummy variable of whether the firm was in a low-carbon province and low-carbon city pilot region in that year. It can see that the coefficients of the ETS variables, although slightly decreasing, are still significant at the

${ }^{3}$ The pilot areas are the five provinces of Guangdong, Liaoning, Hubei, Shaanxi and Yunnan and the eight cities of Tianjin, Chongqing, Shenzhen, Xiamen, Hangzhou, Nanchang, Guiyang and Baoding 
TABLE 3 | Robustness checks.

\begin{tabular}{|c|c|c|c|c|c|c|c|c|}
\hline $\begin{array}{l}\text { Dependent } \\
\text { variable }\end{array}$ & $\begin{array}{l}\text { DDBTD } \\
\text { (1) }\end{array}$ & $\begin{array}{l}\text { DDBTD } \\
\text { (2) }\end{array}$ & $\begin{array}{l}\text { DDBTD } \\
\text { (3) }\end{array}$ & $\begin{array}{l}\text { DDBTD } \\
(4)\end{array}$ & $\begin{array}{l}\text { ETR } \\
(5)\end{array}$ & $\begin{array}{l}\text { DDBTD } \\
(6)\end{array}$ & $\begin{array}{l}\text { DDBTD } \\
(7)\end{array}$ & $\begin{array}{c}\text { DDBTD } \\
\text { (8) }\end{array}$ \\
\hline ETS & $\begin{array}{l}0.0082^{\star \star} \\
(0.0034)\end{array}$ & $\begin{array}{l}0.0080^{\star \star} \\
(0.0034)\end{array}$ & $\begin{array}{l}0.0082^{\star *} \\
(0.0034)\end{array}$ & & $\begin{array}{l}-0.0110^{\star} \\
(0.0062)\end{array}$ & $\begin{array}{l}0.0154^{*} \\
(0.0083)\end{array}$ & $\begin{array}{l}0.0090^{\star \star \star} \\
(0.0034)\end{array}$ & $\begin{array}{c}0.0033 \\
(0.0056)\end{array}$ \\
\hline ETS1 & & & & $\begin{array}{c}0.0131^{\star \star \star} \\
(0.0043)\end{array}$ & & & & \\
\hline Constant & $\begin{array}{l}-0.0157 \\
(0.0315)\end{array}$ & $\begin{array}{l}-0.0170 \\
(0.0309)\end{array}$ & $\begin{array}{l}-0.0186 \\
(0.0309)\end{array}$ & $\begin{array}{l}-0.0080 \\
(0.0710)\end{array}$ & $\begin{array}{c}0.0284 \\
(0.1034)\end{array}$ & $\begin{array}{l}-0.0271 \\
(0.0332)\end{array}$ & $\begin{array}{l}-0.0312 \\
(0.0397)\end{array}$ & $\begin{array}{c}0.0154 \\
(0.0615)\end{array}$ \\
\hline Observations & 9,008 & 9,008 & 9,008 & 2,127 & 9,002 & 9,008 & 9,008 & 2,206 \\
\hline R-squared & 0.0353 & 0.0354 & 0.0352 & 0.0349 & 0.0384 & 0.0784 & 0.0358 & 0.0475 \\
\hline Province ${ }^{\star}$ Trend & $\mathrm{N}$ & $\mathrm{N}$ & $\mathrm{N}$ & $\mathrm{N}$ & $\mathrm{N}$ & Y & $\mathrm{N}$ & $\mathrm{N}$ \\
\hline $\begin{array}{l}\text { Province } \\
\text { characteristics }\end{array}$ & $\mathrm{N}$ & $\mathrm{N}$ & $\mathrm{N}$ & $\mathrm{N}$ & $N$ & Y & Y & $\mathrm{N}$ \\
\hline Firm characteristics & $Y$ & Y & Y & Y & Y & Y & Y & Y \\
\hline Firm FE & Y & Y & Y & Y & Y & Y & Y & Y \\
\hline Year FE & $\mathrm{Y}$ & Y & $\mathrm{Y}$ & Y & Y & Y & Y & Y \\
\hline
\end{tabular}

Note: ${ }^{* *},{ }^{* *}$, and ${ }^{*}$ represent the significance levels at 1, 5, and 10\%, respectively. The robust standard error is reported in parentheses.

$5 \%$ level, which indicates that our estimation results are not affected by the low-carbon region policy.

\subsubsection{Excluding the Disturbance of "Replace Business Tax With Value-Added Tax Policy"}

To reduce double taxation, China started a pilot reform in 2012 to convert firms to replace business tax with Value-Added Tax. The implementation of the reform has changed the phenomenon of industrial firms not being able to obtain credits for services they previously purchased, eliminating tax barriers between upstream and downstream industries such as transportation and manufacturing, and also reducing the tax burden (Liao and Pan, 2015). The reduced tax burden of firms brought by the "replace business tax with Value-Added Tax policy" may offset the effect of the carbon emissions trading policy on corporate tax avoidance, leading to an underestimation of our results. In column 3) of Table 3, we control for the dummy variable of whether or not the "camp reform" was implemented in the year in which the firm is located, and conclude that the coefficient of the ETS variable is still significantly positive, indicating that our results are robust again.

\subsection{Further Robustness Tests}

\subsubsection{Redefining the Treatment and Control Groups}

In the basic regressions, we define the firms located in the pilot regions of carbon emissions trading as the treatment group and the firms in the non-pilot areas as the control group. To exclude the differences between provinces, we narrow the study to the pilot regions. Theoretically, the policy effects of the pilot reform of carbon emission trading rights are mainly concentrated on firms in high-carbon industries and have less effect on other firms. Based on the list of key emission control firms announced by each region, we have identified high carbon industries. We set the companies that belong to the high-carbon industry in the pilot area as the treatment group, and the companies that do not belong to the high-carbon industry as the control group. Then reregress the model 1). The results in column 4) of Table 3 show that the coefficient of ETS is positive and slightly increasing. Significant at the $1 \%$ significance level, indicating that implementing the carbon emission trading rights policy significantly enhances the level of tax avoidance of firms affected by the carbon emission trading rights system. The basic conclusion is robustly present.

\subsubsection{Replacement of Explanatory Variable}

In column 5) of Table 3, we test whether the baseline results depend on the measure of corporate tax avoidance. Instead of the DDBTD indicator after excluding the surplus management factor, we use the ETR indicator, which is also widely used in the literature to measure corporate tax avoidance (Hanlon and Heitzman, 2010; Geng et al., 2021). The lower the value, the higher the level of tax avoidance. Column 5) of Table 3 shows that the regression coefficient of ETS is significantly negative. This indicates that the carbon ETS policy significantly reduces the actual tax burden of firms, i.e., it increases the level of corporate tax avoidance, indicating that our result is not affected by index of corporate tax avoidance.

\subsubsection{Adding Control Variables}

To reduce the effect of omitted variables on the estimation results, we include an interaction term between the province dummy variable and the time trend term in column 6) of Table 3 to control changes over time across provinces. We control province-level control variables in column 7) of Table 3, such as regional industrial structure, total imports and exports as a share of GDP, and regional tax revenue growth rate. The results show that the baseline results are robust.

\subsection{Placebo Test}

\subsubsection{Substitution for Firms Not Subject to Policy Intervention}

In the parallel trend test, we confirm no systematic difference between the treatment and control groups before the carbon trading rights policy pilot. However, if there is an effect of other potentially unobservable factors that make systematic differences between the treatment and control groups after the introduction of the carbon trading pilot, it may result in our baseline results being due to other factors. A reasonable conjecture is that if corporate tax avoidance in pilot and non-pilot areas is affected by 


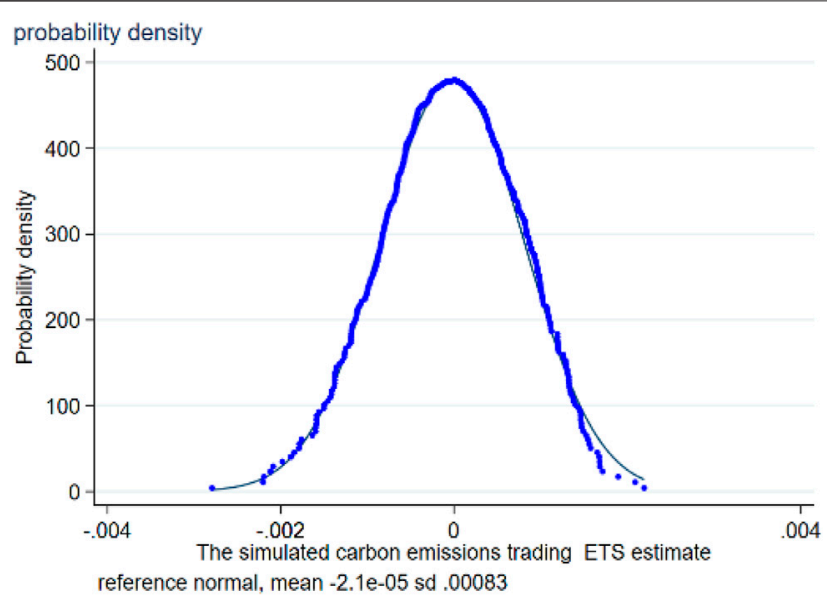

FIGURE 2 | Placebo test

other factors, it will inevitably also affect firms not affected by the carbon trading rights policy. As a result, we conducted a placebo test on firms in the pilot and non-pilot regions that are not part of the high-carbon industries, defined as the treatment and control groups according to the definition of high-carbon industries defined in Section 4.4.1. Theoretically, suppose the pilot carbon trading rights cause the increase in tax avoidance. In that case, the newly defined treatment group and control group are not affected by the pilot carbon trading rights. So the coefficient of ETS should not be significant at this time. Column 8) of Table 3 reports the results of the placebo test, and the coefficients of ETS are not significant, indicating that our baseline results are robust.

\subsubsection{Configuration of Spurious Treatment Groups}

To check whether the results are affected by omitted variables, referring to Chetty et al. (2009) and Li et al. (2016), we randomly assign the implementation of the carbon trading rights policy to each region to conduct the placebo test. By randomly assigning each province's treatment status, we can make the policy shock of carbon trading rights to firms in each province random and obtain random fictitious treatment groups and random coefficient estimates. If the spurious treatment variables significantly affect tax avoidance, it indicates that our baseline results may be biased. Figure 2 illustrates the distribution of the random coefficient estimates $\hat{\beta}^{\text {random }}$ extracted by repeating model 1) 500 times, and it can observe that the mean value of the random coefficient estimates is close to zero, and the estimated coefficients reported in column 2) of Table 2 are significant outliers in the placebo test. These observations suggest that the baseline results are driven by carbon emissions trading policy rather than unobserved factors.

\section{FURTHER DISCUSSION}

\subsection{Heterogeneity Analysis \\ 5.1.1 Nature of Ownership}

State-owned enterprises (SOEs) and non-SOEs may differ in terms of their tax avoidance actions. SOEs are naturally more politically connected to the government and have greater bargaining power with regulators. Furthermore, they can absorb the additional costs associated with policies (Huang, 2003). And executives of SOEs have an incentive to please the government by paying taxes generously, with lower incentives to adopt tax avoidance to obtain funds (Bradshaw et al., 2019). In addition, the government-controlled background of SOEs allows them to receive large supportive government subsidies and bank loans, face a more relaxed financing environment and lower financing costs (Liu et al., 2016; Zhang et al., 2019), so SOEs are less likely to be in financial distress. Hering and Poncet (2014) find that China's Sulphur dioxide emissions trading rights pilot policy significantly reduced exports from the pilot provinces, and the effect is more evident on private firms. Especially because better access to financing made it easier for SOEs to use advanced technologies, thus enabling them to stay in business as environmental regulation tightened. In columns 1) and 2) of Table 4, we regress model 1) on the sample of non-SOEs and SOEs separately, and the findings show that the effect of carbon emissions trading policy on corporate tax avoidance is mainly present in non-SOEs, while it is not significant in SOEs.

\subsubsection{Degree of Financing Constraints}

Firms with severe financing constraints have poor access to external financing and higher cost of financing, and are more likely to resort to internal financing such as tax avoidance to save cash flow to alleviate financing constraints when subjected to policy shocks (Law and Mills, 2015; Edwards et al., 2016). We use the SA index, which is commonly used in the literature, as a proxy variable for the degree of a corporate financing constraints (Hadlock and Pierce, 2010). The SA index is calculated using the formula: $S A$ Index $=-0.737 \times$ Asset $+0.043 \times$ Asset $^{2}-$ $0.040 \times A g e$. Where Asset is the logarithm of the corporate total assets and Age is the corporate age. A higher SA index represents a more severe financing constraint. In terms of variable definitions, firms are ranked from the highest to the lowest degree of financing constraint for each industry in each observation year. If a corporate rank is in the top (bottom) 50\% of all firms in the industry, the firm is considered the group with a high (low) degree of financing constraint. Columns 3) and 4) of Table 4 demonstrate the groups with high and low financing constraints, respectively. The coefficients of ETS variables are significantly positive only in the group with a high degree of corporate financing constraints. It indicates that the effect mainly exists in firms facing a high degree of financing constraints, while it is not significant in firms with a low degree of financing constraints.

\subsubsection{Degree of Industry Competition}

Intuitively, the higher competitive pressure a firm faces, the more likely it will avoid taxes to have more cash for investment to compete in the market. Cai and Liu (2009) examined the effect of competitive market pressure on corporate income tax avoidance. They found that the higher competitive market pressure a firm faces, tax avoidance is more severe. Bulan et al. (2009) pointed out that when market competition becomes fierce, the reduction of corporate profit margins weakens the ability of companies to 
TABLE 4 | Heterogeneity analysis.

\begin{tabular}{|c|c|c|c|c|c|c|}
\hline Dependent variable & $\begin{array}{c}\text { DDBTD } \\
\text { Non-SOEs }\end{array}$ & $\begin{array}{l}\text { DDBTD } \\
\text { SOEs }\end{array}$ & $\begin{array}{l}\text { DDBTD } \\
\text { Large financing } \\
\text { constraints } \\
\text { (3) }\end{array}$ & $\begin{array}{c}\text { DDBTD } \\
\text { Small financing } \\
\text { constraints } \\
\text { (4) }\end{array}$ & $\begin{array}{c}\text { DDBTD } \\
\text { High level } \\
\text { of market } \\
\text { competition } \\
\text { (5) }\end{array}$ & $\begin{array}{c}\text { DDBTD } \\
\text { Low level } \\
\text { of market } \\
\text { competition } \\
\text { (6) }\end{array}$ \\
\hline ETS & $\begin{array}{l}0.0119^{\star \star} \\
(0.0053)\end{array}$ & $\begin{array}{c}0.0052 \\
(0.0038)\end{array}$ & $\begin{array}{l}0.0119^{\star \star} \\
(0.0046)\end{array}$ & $\begin{array}{c}0.0018 \\
(0.0047)\end{array}$ & $\begin{array}{c}0.0132^{\star \star \star} \\
(0.0050)\end{array}$ & $\begin{array}{c}0.0022 \\
(0.0057)\end{array}$ \\
\hline Constant & $\begin{array}{l}-0.0633 \\
(0.0415)\end{array}$ & $\begin{array}{c}0.0610 \\
(0.0563)\end{array}$ & $\begin{array}{c}0.0847 \\
(0.0902)\end{array}$ & $\begin{array}{l}-0.0406 \\
(0.0431)\end{array}$ & $\begin{array}{l}-0.0306 \\
(0.0444)\end{array}$ & $\begin{array}{l}-0.0060 \\
(0.0558)\end{array}$ \\
\hline Observations & 5,383 & 3,625 & 4,544 & 4,464 & 3,989 & 3,876 \\
\hline R-squared & 0.0329 & 0.0383 & 0.0376 & 0.0428 & 0.0302 & 0.0519 \\
\hline Firm characteristics & Y & Y & Y & Y & Y & Y \\
\hline Firm FE & Y & Y & Y & Y & Y & Y \\
\hline Year FE & Y & Y & Y & Y & Y & Y \\
\hline
\end{tabular}

Note: ${ }^{* * *},{ }^{* *}$, and * represent the significance levels at 1,5 , and $10 \%$, respectively. The robust standard error is reported in parentheses.

create cash flow and releases signals of decline in debt solvency. Therefore, competition will increase the difficulty of external financing for companies. Furthermore, when firms are subject to policy shocks, the increase in economic burden is not entirely borne by shareholders, but it is passed on to customers under certain conditions. Smale et al. (2006) pointed out that firms in carbon trading pilots can pass on the cost of carbon to consumers by raising prices. However, when the market is highly competitive, it is difficult for companies to pass on. Therefore, firms in a competitive market may have a greater incentive to evade taxes. We use the CR10 index to measure the degree of market competition (Hall and Tideman, 1967; Cai and Liu, 2009), which represents the ratio of the ten largest firms in the industry to industry-wide sales (CR10) as a proxy for the degree of competition in the industry. In the definition of the variable, the industry is ranked from the highest to the lowest level of competitive intensity. If a corporate industry is in the top (bottom) $50 \%$ of competitive intensity, the firm is considered in the group with a high (low) level of industry competition. Columns 5) and 6) of Table 4 show the groups with high and low industry competitive intensity, respectively. The findings show that the coefficients of ETS variables are significant in industries with high industry competitive intensity. It indicates that the enhancement effect of environmental regulation on corporate tax avoidance mainly exists in firms with high industry competition and is not significant in firms with low industry competition.

\subsection{Mechanism Analysis}

\subsubsection{Cash Flow Level}

The increased intensity of environmental regulations may increase the cost of corporate investment in environmental protection equipment and pollutant treatment improvements, resulting in higher actual product costs, which reduces the competitiveness of corporate products given the same product quality, leading to lower sales or exports of corporate products (Hering and Poncet, 2014), and exacerbating corporate cash flow constraints. Chen et al. (2021) pointed out that China's carbon emissions trading policy pilot reduced corporate output, operating income, main operating costs, and net cash flow.
The reduced level of corporate cash flow after implementing carbon emissions trading policy may be one of the reasons for corporate tax avoidance. In this paper, we use the net cash flow generated by the corporate operating activities after adjusting total assets as a measure of the corporate operating cash flow. In column 1) of Table 5, we replace the explanatory variable in model 1) with cash flow level. The result shows that operating cash flow is significantly lower for firms in the carbon emissions trading pilot region. Further, in column 2) of Table 5, we replace the explanatory variable with the corporate current ratio, calculated by the corporate current assets to current liabilities. In this way, we will examine the changes in the solvency of companies after implementing the carbon emissions trading policy. The result shows that the solvency of firms has declined significantly after the implementation of the trading pilot, which the decline in profitability may cause.

\subsubsection{Corporate Innovation Capability}

The increase in R\&D investment demand of the regulated firms after implementing the carbon trading pilot may be one of the channels for firms to avoid taxes. Existing studies have not reached a unanimous conclusion on the research of carbon emissions trading on corporate green innovation (Shi et al., 2018; Wang et al., 2019; Chen et al., 2021). On the one hand, before the establishment of the carbon emission trading rights system, firms faced a more relaxed carbon emission reduction constraint, the cost of carbon emissions was low, and the incentive to reduce emissions was not high. After implementing the carbon emissions trading pilot, firms were forced into the carbon market aggregate control increased the cost of carbon emissions, prompting firms $s$ to tend to reduce their own emission reduction costs by increasing $R \& D$ investment to achieve low-carbon technology transformation (Wang et al., 2019). On the other hand, the reduction of corporate cash flow and expected revenue after implementing the carbon emissions trading policy may reduce corporate $R \& D$ investment (Chen et al., 2021). We replace the explained variable in column 3) of Table 5 with the corporate green innovation measured by the logarithm of the number of corporate green 
TABLE 5 | Potential mechanisms.

\begin{tabular}{|c|c|c|c|c|c|c|}
\hline Dependent variable & $\begin{array}{l}\text { Cash } \\
\text { (1) }\end{array}$ & $\begin{array}{l}\text { Current ratio } \\
\text { (2) }\end{array}$ & $\begin{array}{l}\text { R\&D input } \\
\text { (3) }\end{array}$ & $\begin{array}{l}\text { Fixed-asset } \\
\text { investment } \\
\text { (4) }\end{array}$ & $\begin{array}{c}\text { Management expenses } \\
\text { (5) }\end{array}$ & $\begin{array}{c}\text { Operating risks } \\
\text { (6) }\end{array}$ \\
\hline ETS & $\begin{array}{c}-0.0115^{\star} \\
(0.0066)\end{array}$ & $\begin{array}{c}-0.1920^{\star} \\
(0.1054)\end{array}$ & $\begin{array}{c}-0.1541^{\star \star} \\
(0.0598)\end{array}$ & $\begin{array}{c}0.0007 \\
(0.0039)\end{array}$ & $\begin{array}{c}0.0016 \\
(0.0028)\end{array}$ & $\begin{array}{l}-0.0012 \\
(0.0017)\end{array}$ \\
\hline Constant & $\begin{array}{l}1.3653^{\star \star} \\
(0.5784)\end{array}$ & $\begin{array}{l}2.8029^{\star} \\
(1.6279)\end{array}$ & $\begin{array}{c}-5.3568^{\star \star \star} \\
(0.9061)\end{array}$ & $\begin{array}{c}0.2367^{\star \star \star} \\
(0.0523)\end{array}$ & $\begin{array}{c}0.2757^{\star \star \star} \\
(0.0496)\end{array}$ & $\begin{array}{c}0.0505^{\star \star \star} \\
(0.0189)\end{array}$ \\
\hline Observations & 8,492 & 8,996 & 9,008 & 8,425 & 8,996 & 7,869 \\
\hline R-squared & 0.1047 & 0.4020 & 0.1697 & 0.1945 & 0.1184 & 0.1286 \\
\hline Firm characteristics & Y & Y & Y & Y & Y & Y \\
\hline Firm FE & Y & Y & Y & Y & Y & Y \\
\hline Year FE & Y & Y & Y & $Y$ & Y & Y \\
\hline
\end{tabular}

Note: ${ }^{* *},{ }^{* *}$, and * represent the significance levels at 1, 5, and 10\%, respectively. The robust standard error is reported in parentheses.

patent applications, where a larger number of corporate green patent applications represents a higher level of corporate green innovation. The coefficient of the ETS variable is significantly negative, and the result suggests that the carbon emissions trading policy reduces the level of corporate green innovation. After implementing the carbon emissions trading policy, firms did not enhance their R\&D investment, indicating that the increase in $\mathrm{R} \& \mathrm{D}$ investment is not a channel for firms to avoid taxes.

\subsubsection{Corporate Capital Investment}

To reduce the cost of carbon emissions, emission-controlled firms need to invest a large amount of capital for upgrading production equipment, and corporate tax avoidance may be motivated by corporate capital investment needs. Drawing on Richardson (2006) measure of intra-firm investment, we define intra-firm investment as (cash paid for the purchase of fixed assets, intangible assets, and other long-term assets - net cash recovered from the disposal of fixed assets, intangible assets, and other long-term assets - depreciation) as a proportion of total assets. Column 4) of Table 5 explores whether carbon emissions trading policy increase firms' internal investment by including the amount of internal investment as an explanatory variable. The conclusion shows that the coefficients of the ETS variables are not significant, indicating that the increased level of corporate tax avoidance caused by the carbon emissions trading policy is not due to an increase in the amount of internal investment by the regulated firms.

\subsubsection{Corporate Overhead Costs}

The increase in business management costs due to the carbon emissions trading policy may motivate corporate tax avoidance. Tightening environmental regulation may impose new constraints on corporate production and management decisions, prompting them to provide environmentally compatible products and services. When external environmental regulation change, firms need to incorporate various environmental policies and plans into their operational strategies and adjust specific behaviors regarding product design, process technology selection, management techniques, production processes, quality management, and other related business management (Gupta, 1995). After implementing carbon emission policies, companies may implement aggressive carbon reduction plans, initiate environment-related performance measures, and adjust their original organizational frameworks, bringing about a significant increase in corporate management costs. We use the share of corporate overhead costs in operating income as a measure of corporate overhead costs, and try to explore whether the facilitation effect of environmental regulation on corporate tax avoidance is due to the increase in overhead costs by the change in overhead costs of pilot firms. The findings in column 5) of Table 5 show that the coefficients of the ETS variables do not show statistical significance, indicating that the carbon emissions trading policy did not increase corporate overhead costs. The increase in the degree of corporate tax avoidance after the post-pilot implementation may not be caused by an increase in corporate overhead costs.

\subsubsection{Operational Risk}

The existing literature suggests that strict environmental regulation can change firms' original operating patterns and impose additional constraints on their production decisions, thus increasing their operational risks (Peng et al., 2021). When companies face the effect of carbon emissions trading policy, they may increase tax avoidance activities for preventive motives to withstand the uncertainties and risks they face. Geng et al. (2021) confirmed that after facing stricter environmental regulation brought about by the "11th Five-Year Plan", companies have increased corporate tax avoidance. We refer to the practice of Dhaliwal et al. (2011) and define the company's operational risk (OR) as the standard deviation of the company's return on total assets in the next 3 years, and use $\mathrm{OR}$ as the explained variable to explore the effect of carbon trading emissions on affected companies. The effect of operational risks. The regression results in column 6) of Table 5 show that the regression coefficients of the EST variables are not significant, indicating that the implementation of carbon trading emission policies has not had a significant effect on corporate operational risks, and the increase in corporate operational risks is not the primary motivation for corporate tax avoidance.

\subsection{Effect of Government Subsidies}

Carbon trading emission policy brings additional costs for firms, making firms face more financing constraints and lower liquidity 
TABLE 6 | Government subsidies and corporate tax avoidance.

\begin{tabular}{lccc}
\hline Dependent variable & $\begin{array}{c}\text { DDBTD } \\
(\mathbf{1})\end{array}$ & $\begin{array}{c}\text { DDBTD } \\
\mathbf{( 2 )}\end{array}$ & $\begin{array}{c}\text { DDBTD } \\
\mathbf{( 3 )}\end{array}$ \\
\hline ETS & 0.0054 & $0.0111^{\star}$ & $0.0110^{\star \star \star}$ \\
& $(0.0052)$ & $(0.0057)$ & $(0.0041)$ \\
Subsidy & & & $0.0434^{\star \star}$ \\
& & & $(0.0215)$ \\
ETS*Subsidy & & & $-0.1165^{\star \star}$ \\
& & & $(0.0572)$ \\
Constant & 0.0035 & -0.0618 & -0.0243 \\
& $(0.0519)$ & $(0.0478)$ & $(0.0318)$ \\
Observations & 4,267 & 4,514 & 8,781 \\
R-squared & 0.0384 & 0.0326 & 0.0379 \\
Firm characteristics & $Y$ & $Y$ & $Y$ \\
Firm FE & $Y$ & $Y$ & $Y$ \\
Year FE & $Y$ & $Y$ & $Y$ \\
& & &
\end{tabular}

Note: ***, **, and * represent the significance levels at 1, 5, and 10\%, respectively. The robust standard error is reported in parentheses.

as an important motive for tax avoidance. In contrast, government subsidies can bring direct cash flow to firms and improve their financial liquidity. Government subsidies can reduce a series of sunk costs brought by corporate innovation and $R \& D$ and help firms resist the risk and loss of R\&D failure, thus reducing the incentive of tax avoidance. In addition to directly supplementing corporate capital, government subsidies can release positive signals to the outside world, attract social resources to gather, alleviate corporate financing difficulties and guide market expectations, further weakening corporate tax avoidance incentives in an environment of economic policy uncertainty. Columns 1) and 2) of Table 6 distinguish between the subsamples with high and low government subsidies levels. The regressions conclude that the effect of carbon emissions trading policy on corporate tax avoidance is mainly found in firms with low levels of government subsidies. Column 3) of Table 6 incorporates the interaction term between government subsidies and ETS in an attempt to explore the moderating effect of government subsidies on environmental regulation and corporate tax avoidance, and the findings indicate that the facilitating effect of environmental regulation on corporate tax avoidance is weakened for firms that receive higher government subsidies.

\section{CONCLUSION}

As ecological improvement becomes a global consensus, marketincentivized environmental regulation tools are increasingly. Environmental regulation triggers adjustments in firm behavior. Based on a quasi-natural experiment of carbon trading emission, this paper explored the effect of marketincentivized environmental regulation on corporate tax avoidance using a sample of industrial firms listed in China. The results show that 1) Market-incentivized environmental regulation significantly increase the level of tax avoidance of firms in the region where the carbon trading rights pilot is implemented. Our findings remain robust after conducting robustness tests such as excluding the confounding effects of contemporaneous policies, reclassifying the control and control groups, replacing the measure of corporate tax avoidance, and including more control variables. 2) Heterogeneity analysis shows that tax avoidance significantly increases for non-state-owned firms, firms with severe financing constraints, and firms in competitive industries after a policy shock. 3) Mechanistic analysis suggests that the decrease of cash flow may be a channel affecting corporate tax avoidance. 4) Government subsidies help mitigate the elevated effect of environmental regulation on corporate tax avoidance. The more government subsidies a company receives, the less tax avoidance it has.

The results of this paper provide insights into the implementation of carbon emissions trading policy. When firms face stricter environmental regulation, they resort to tax avoidance to defray the costs associated with the policy. When assessing the cost of carbon policies, governments should also pay attention to the effect of the policies on the tax avoidance behavior of different firms. Based on the results of this paper, we offer the following suggestions: 1) Strengthen the cooperation between environmental protection departments and other departments. Share data and information with tax authorities to increase enforcement against regulated firms and curb unreasonable tax avoidance. 2) Reducing corporate cash flow is the main motivation for corporate tax avoidance. To cope with the crowding out of corporate cash by emissions cost after implementing carbon emissions trading policy, environmental protection departments should help the private firms and financing constraints serious firms to broaden financing channels. 3) To encourage green R\&D investment and low-carbon technology innovation, the government should continue to increase tax incentives such as tax deductions for $\mathrm{R} \& \mathrm{D}$ expenses, and give subsidies to regulated firms through various support policies.

\section{DATA AVAILABILITY STATEMENT}

The original contributions presented in the study are included in the article/Supplementary Material, further inquiries can be directed to the corresponding author.

\section{AUTHOR CONTRIBUTIONS}

CF: Conceptualization, Writing-Original Draft, Writing-Review and Editing. XZ: Investigation, Writing-Original Draft, Writing-Reviewing and Editing. YG: Methodogy, Data Curation, Software, Writing-Original Draft, Writing-Review and Editing. YL: Investigation, Methodology, Data Curation, Writing-Original Draft.

\section{FUNDING}

This paper is supported by the Programme of Introducing Talents of Discipline to Universities (No. B20084). We declare all sources of funding received for the research being submitted. 


\section{REFERENCES}

Abrell, J., Faye, A. N., and Zachmann, G. (2008). Assessing the Impact of the EU ETS Using Firm Level Data. Brussels: Bruegel Working Paper.

Allingham, M. G., and Sandmo, A. (1972). Income Tax Evasion: A Theoretical Analysis. J. Publ. Econ. 1 (3-4), 323-338. doi:10.1016/0047-2727(72)90010-2

Beck, T., Lin, C., and Ma, Y. (2014). Why Do Firms Evade Taxes? the Role of Information Sharing and Financial Sector Outreach. J. Finance 69 (2), 763-817. doi:10.1111/jofi.12123

Blundell, R., and Costa Dias, M. (2020). Evaluation Methods for Non-experimental Data. Fisc. Stud. 21 (4), 427-468. doi:10.1111/j.1475-5890.2000.tb00031.x

Bradshaw, M., Liao, G., and Ma, M. (2019). Agency Costs and Tax Planning when the Government Is a Major Shareholder. J. Account. Econ. 67 (2/3), 255-277. doi:10.1016/j.jacceco.2018.10.002

Bulan, L., Mayer, C., and Somerville, C. T. (2009). Irreversible Investment, Real Options, and Competition: Evidence from Real Estate Development. J. Urban Econ. 65 (3), 237-251. doi:10.1016/j.jue.2008.03.003

Cai, H., and Liu, Q. (2009). Competition and Corporate Tax Avoidance: Evidence from Chinese Industrial Firms. Econ.J. 119 (537), 764-795. doi:10.1111/j.14680297.2009.02217.x

Cai, X., Lu, Y., Wu, M., and Yu, L. (2016). Does Environmental Regulation Drive Away Inbound Foreign Direct Investment? Evidence from a Quasi-Natural Experiment in China. J. Develop. Econ. 123, 73-85. doi:10.1016/ j.jdeveco.2016.08.003

Chen, S. X. (2017). The Effect of a Fiscal Squeeze on Tax Enforcement: Evidence from a Natural Experiment in China. J. Public Econ. 147, 62-76. doi:10.1016/ j.jpubeco.2017.01.001

Chen, Z., Zhang, X., and Chen, F. (2021). Do Carbon Emission Trading Schemes Stimulate Green Innovation in Enterprises? Evidence from China. Technol. Forecast. Soc. Change 168, 120744. doi:10.1016/j.techfore.2021.120744

Chetty, R., Looney, A., and Kroft, K. (2009). Salience and Taxation: Theory and Evidence. Am. Econ. Rev. 99 (4), 1145-1177. doi:10.1257/aer.99.4.1145

Dang, D., Fang, H., and He, M. (2019). Economic Policy Uncertainty, Tax Quotas and Corporate Tax burden: Evidence from China. China Econ. Rev. 56, 101303. doi:10.1016/j.chieco.2019.101303

Desai, M. A., and Dharmapala, D. (2006). Corporate Tax Avoidance and HighPowered Incentives. J. Financial Econ. 79 (1), 145-179. doi:10.1016/ j.jfineco.2005.02.002

Dhaliwal, D., Lee, H. S., and Neamtiu, M. (2011). The Impact of Operating Leases on Firm Financial and Operating Risk. J. Account. Auditing Finance 26 (2), 151-197. doi:10.1177/0148558X11401210

Dong, C., Dong, X., Jiang, Q., Dong, K., and Liu, G. (2018). What Is the Probability of Achieving the Carbon Dioxide Emission Targets of the Paris Agreement? Evidence from the Top Ten Emitters. Sci. Total Environ. 622-623, 1294-1303. doi:10.1016/j.scitotenv.2017.12.093

Dong, F., Dai, Y., Zhang, S., Zhang, X., and Long, R. (2019). Can a Carbon Emission Trading Scheme Generate the Porter Effect? Evidence from Pilot Areas in China. Sci. Total Environ. 653, 565-577. doi:10.1016/j.scitotenv.2018.10.395

Dong, K., Shahbaz, M., and Zhao, J. (2022). How Do Pollution Fees Affect Environmental Quality in China. Energy Policy 160, 112695. doi:10.1016/ j.enpol.2021.112695

Dudley, E., and Zhang, N. (2016). Trust and Corporate Cash Holdings. J. Corporate Finance 41, 363-387. doi:10.1016/j.jcorpfin.2016.10.010

Edwards, A., Schwab, C., and Shevlin, T. (2016). Financial Constraints and Cash Tax Savings. Account. Rev. 91 (3), 859-881. doi:10.2308/accr-51282

Falkinger, J. (1995). Tax Evasion, Consumption of Public Goods and Fairness. J. Econ. Psychol. 16 (1), 63-72. doi:10.1016/0167-4870(94)00038-c

Fallan, E., and Fallan, L. (2019). Corporate Tax Behaviour and Environmental Disclosure: Strategic Trade-Offs across Elements of CSR. Scand. J. Manage. 35 (3), 101042. doi:10.1016/j.scaman.2019.02.001

Geng, Y., Liu, W., Li, K., and Chen, H. (2021). Environmental Regulation and Corporate Tax Avoidance: A Quasi-Natural Experiment Based on the Eleventh Five-Year Plan in China. Energ. Econ. 99, 105312. doi:10.1016/ j.eneco.2021.105312

Godfrey, P. C. (2005). The Relationship between Corporate Philanthropy and Shareholder Wealth: A Risk Management Perspective. Amr 30 (4), 777-798. doi:10.5465/AMR.2005.18378878
Gray, W., B. (1987). The Cost of Regulation: OSHA, EPA and the Productivity Slowdown. Am. Econ. Rev. 77 (5), 998-1006. Available at: http://www.jstor.org/ stable/1810223.

Gupta, M. C. (1995). Environmental Management and its Impact on the Operations Function. Int. Jrnl Op Prod. Mnagemnt 15 (8), 34-51. doi:10.1108/01443579510094071

Gupta, S., and Newberry, K. (1997). Determinants of the Variability in Corporate Effective Tax Rates: Evidence from Longitudinal Data. J. Account. Public Pol. 16 (1), 1-34. doi:10.1016/s0278-4254(96)00055-5

Hadlock, C. J., and Pierce, J. R. (2010). New Evidence on Measuring Financial Constraints: Moving beyond the KZ Index. Rev. Financ. Stud. 23 (5), 1909-1940. doi:10.1093/rfs/hhq009

Hall, M., and Tideman, N. (1967). Measures of Concentration. J. Am. Stat. Assoc. 62 (317), 162-168. doi:10.1080/01621459.1967.10482897

Hanlon, M., and Heitzman, S. (2010). A Review of Tax Research. J. Account. Econ. 50, 127-178. doi:10.1016/j.jacceco.2010.09.002

Hering, L., and Poncet, S. (2014). Environmental Policy and Exports: Evidence from Chinese Cities. J. Environ. Econ. Manage. 68 (2), 296-318. doi:10.1016/ j.jeem.2014.06.005

Huang, Y. S. (2003). Selling China: Foreign Direct Investment during the Reform Era. New York, NY: Cambridge University Press.

Jacobson, L. S., Lalonde, R. J., and Sullivan, D. G. (1993). Earnings Losses of Displaced Workers. Am. Econ. Rev. 83, 685-709. doi:10.17848/wp92-11

Jong, T., Couwenberg, O., and Woerdman, E. (2014). Does EU Emissions Trading Bite? an Event Study. Energy Policy 69, 510-519. doi:10.1016/ j.enpol.2014.03.007

Kanagaretnam, K., Lee, J., Lim, C. Y., and Lobo, G. J. (2018). Cross-Country Evidence on the Role of Independent Media in Constraining Corporate Tax Aggressiveness. J. Bus. Ethics 150 (3), 879-902. doi:10.1007/s10551-0163168-9

Khurana, I. K., and Moser, W. J. (2013). Institutional Shareholders' Investment Horizons and Tax Avoidance. J. Am. Tax. Assoc. 35 (1), 111-134. doi:10.2308/ atax-50315

Kleven, H., J., Knudsen, M. B., Kreiner, C. T., Pedersen, S., and Saez, E. (2011). Unwilling or Unable to Cheat? Evidence from a Tax Audit Experiment in Denmark. Econometrica 79 (3), 651-692. doi:10.3982/ecta9113

Koch, N., and Bassen, A. (2013). Valuing the Carbon Exposure of European Utilities. The Role of Fuel Mix, Permit Allocation and Replacement Investments. Energ. Econ. 36, 431-443. doi:10.1016/j.eneco.2012.09.019

Kubick, T. R., Lynch, D. P., Mayberry, M. A., and Omer, T. C. (2015). Product Market Power and Tax Avoidance: Market Leaders, Mimicking Strategies, and Stock Returns. Account. Rev. 90 (2), 675-702. doi:10.2308/accr-50883

Law, K. K. F., and Mills, L. F. (2015). Taxes and Financial Constraints: Evidence from Linguistic Cues. J. Account. Res. 53 (4), 777-819. doi:10.1111/1475679x.12081

Li, J., Dong, X., and Dong, K. (2021). Do pollutant Discharge Fees Affect Labor Demand? Evidence from China's Industrial Enterprises. Appl. Econ., 1-19. doi:10.1080/00036846.2021.1963662

Li, P., Lu, Y., and Wang, J. (2016). Does Flattening Government Improve Economic Performance? Evidence from China. J. Develop. Econ. 123, 18-37. doi:10.1016/ j.jdeveco.2016.07.002

Liao, S., and Pan, Y. (2015). Analysis on the Policy Effect of Replacing Business Tax with Added-Value Tax. Ijefm 3 (3), 162-171. doi:10.11648/j.ijefm.20150303.13

Liu, M., Zhou, C., Lu, F., and Hu, X. (2021). Impact of the Implementation of Carbon Emission Trading on Corporate Financial Performance: Evidence from Listed Companies in China. PLoS One 16, e0253460. doi:10.1371/ journal.pone. 0253460

Liu, Q., Luo, J., and Tian, G. G. (2016). Managerial Professional Connections versus Political Connections: Evidence from Firms' Access to Informal Financing Resources. J. Corporate Finance 41, 179-200. doi:10.1016/j.jcorpfin.2016.09.003

Mills, L. F., Nutter, S. E., and Schwab, C. M. (2013). The Effect of Political Sensitivity and Bargaining Power on Taxes: Evidence from Federal Contractors. Account. Rev. 88 (3), 977-1005. doi:10.2308/accr-50368

Oestreich, A. M., and Tsiakas, I. (2015). Carbon Emissions and Stock Returns: Evidence from the EU Emissions Trading Scheme. J. Banking Finance 58, 294-308. doi:10.1016/j.jbankfin.2015.05.005

Olsen, K. J., and Stekelberg, J. (2016). CEO Narcissism and Corporate Tax Sheltering. J. Am. Tax. Assoc. 38 (1), 1-22. doi:10.2308/atax-51251 
Peng, J., Xie, R., Ma, C., and Fu, Y. (2021). Market-based Environmental Regulation and Total Factor Productivity: Evidence from Chinese Enterprises. Econ. Model. 95, 394-407. doi:10.1016/j.econmod.2020.03.006

Peng, S., Chang, Y., and Zhang, J. (2015). Consideration of Some Key Issues of Carbon Market Development in China. Chin. J. Popul. Resour. Environ. 13 (1), 10-15. doi:10.1080/10042857.2015.1005344

Pomeranz, D., and Vila-Belda, J. (2019). Taking State-Capacity Research to the Field: Insights from Collaborations with Tax Authorities. Annu. Rev. Econ. 11 (1), 755-781. doi:10.1146/annurev-economics-080218-030312

Porter, M. E., and Linde, C. v. d. (1995). Toward a New Conception of the Environment-Competitiveness Relationship. J. Econ. Perspect. 9 (4), 97-118. doi:10.1257/jep.9.4.97

Rego, S. O. (2003). Tax-Avoidance Activities of U.S. Multinational Corporations* Contemp. Account. Res. 20 (4), 805-833. doi:10.1506/vann-b7ub-gmfa-9e6w

Richardson, G., Taylor, G., and Lanis, R. (2013). The Impact of Board of Director Oversight Characteristics on Corporate Tax Aggressiveness: An Empirical Analysis. J. Account. Public Pol. 32 (3), 68-88. doi:10.1016/ j.jaccpubpol.2013.02.004

Richardson, G., Wang, B., and Zhang, X. (2016). Ownership Structure and Corporate Tax Avoidance: Evidence from Publicly Listed Private Firms in China. J. Contemp. Account. Econ. 12 (2), 141-158. doi:10.1016/ j.jcae.2016.06.003

Richardson, S. (2006). Over-Investment of Free Cash Flow. Rev. Acc. Stud. 11 (2-3), 159-189. doi:10.1007/s11142-006-9012-1

Sari, D., Tjen, C., and Tjen, C. (2016). Corporate Social Responsibility Disclosure, Environmental Performance, and Tax Aggressiveness. Irjbs 9 (2), 93-104. doi:10.21632/irjbs.9.2.93-104

Shao, S., Wang, C., Guo, Y., Xie, B.-C., Tian, Z., and Chen, S. (2021). Heterogeneous Performances and Consequences of China's Industrial Environmental Governance: Clean Production vs. End-Of-Pipe Treatment. J. Environ. Plann. Manage., 1-26. doi:10.1080/09640568.2021.1980377

Shen, J., Wei, Y. D., and Yang, Z. (2017). The Impact of Environmental Regulations on the Location of Pollution-Intensive Industries in China. J. Clean. Prod. 148, 785-794. doi:10.1016/j.jclepro.2017.02.050

Shi, B., Feng, C., Qiu, M., and Ekeland, A. (2018). Innovation Suppression and Migration Effect: The Unintentional Consequences of Environmental Regulation. China Econ. Rev. 49 (1-23), 1-23. doi:10.1016/j.chieco.2017.12.007

Smale, R., Hartley, M., Hepburn, C., Ward, J., and Grubb, M. (2006). The Impact of CO2emissions Trading on Firm Profits and Market Prices. Clim. Pol. 6 (1), 31-48. doi:10.1080/14693062.2006.9685587

Stickney, C. P., and McGee, V. E. (1982). Effective Corporate Tax Rates the Effect of Size, Capital Intensity, Leverage, and Other Factors. J. Account. Public Pol. 1 (2), 125-152. doi:10.1016/S0278-4254(82)80004-5

Wang, H., Chen, Z., Wu, X., and Nie, X. (2019). Can a Carbon Trading System Promote the Transformation of a Low-Carbon Economy under the Framework of the porter Hypothesis? -Empirical Analysis Based on the PSM-DID Method. Energy Policy 129, 930-938. doi:10.1016/j.enpol.2019.03.007
Wang, L., Cui, L., Weng, S., and Liu, C. (2021). Promoting Industrial Structure Advancement through an Emission Trading Scheme: Lessons from China's Pilot Practice. Comput. Ind. Eng. 157, 107339. doi:10.1016/j.cie.2021.107339

Wang, S., Wang, H., Wang, J., and Yang, F. (2020). Does Environmental Information Disclosure Contribute to Improve Firm Financial Performance? an Examination of the Underlying Mechanism. Sci. Total Environ. 714, 136855. doi:10.1016/j.scitotenv.2020.136855

Wilson, R. J. (2009). An Examination of Corporate Tax Shelter Participants. Rev 84, 969-999. doi:10.2308/accr.2009.84.3.969

Xuan, D., Ma, X., and Shang, Y. (2020). Can China's Policy of Carbon Emission Trading Promote Carbon Emission Reduction. J. Clean. Prod. 270, 122383. doi:10.1016/j.jclepro.2020.122383

Ye, B., and Lin, L. (2020). Environmental Regulation and Responses of Local Governments. China Econ. Rev. 60, 101421. doi:10.1016/j.chieco.2020.101421

Yu, H., Liao, L., Qu, S., Fang, D., Luo, L., and Xiong, G. (2021). Environmental Regulation and Corporate Tax Avoidance: A Quasi-Natural Experiments Study Based on China's New Environmental protection Law. J. Environ. Manage. 296, 113160. doi:10.1016/j.jenvman.2021.113160

Zhang, H., Duan, M., and Deng, Z. (2019). Have China's Pilot Emissions Trading Schemes Promoted Carbon Emission Reductions?- the Evidence from Industrial Sub-sectors at the Provincial Level. J. Clean. Prod. 234 (10), 912-924. doi:10.1016/j.jclepro.2019.06.247

Zhao, X., and Sun, B. (2016). The Influence of Chinese Environmental Regulation on Corporation Innovation and Competitiveness. J. Clean. Prod. 112 (2), 1528-1536. doi:10.1016/j.jclepro.2015.05.029

Zheng, Y., Sun, X., Zhang, C., Wang, D., and Mao, J. (2021). Can Emission Trading Scheme Improve Carbon Emission Performance? Evidence from China. Front. Energ. Res. 9, 759572. doi:10.3389/fenrg.2021.759572

Zimmerman, J. L. (1983). Taxes and Firm Size. J. Account. Econ. 5, 119-149. doi:10.1016/0165-4101(83)90008-3

Conflict of Interest: The authors declare that the research was conducted in the absence of any commercial or financial relationships that could be construed as a potential conflict of interest.

Publisher's Note: All claims expressed in this article are solely those of the authors and do not necessarily represent those of their affiliated organizations, or those of the publisher, the editors, and the reviewers. Any product that may be evaluated in this article, or claim that may be made by its manufacturer, is not guaranteed or endorsed by the publisher.

Copyright (C) 2022 Feng, Zhu, Gu and Liu. This is an open-access article distributed under the terms of the Creative Commons Attribution License (CC BY). The use, distribution or reproduction in other forums is permitted, provided the original author(s) and the copyright owner(s) are credited and that the original publication in this journal is cited, in accordance with accepted academic practice. No use, distribution or reproduction is permitted which does not comply with these terms. 